\title{
Effect of hydraulic retention time on performance of an anoxic-aerobic sequencing batch reactor treating saline wastewater
}

\author{
Z. C. Wang $\cdot$ M. C. Gao $\cdot$ Y. Ren $\cdot$ Z. Wang $\cdot$ \\ Z. L. She - C. J. Jin $\cdot$ Q. B. Chang \\ C. Q. Sun $\cdot$ J. Zhang $\cdot$ N. Yang
}

Received: 14 October 2013/Revised: 2 March 2014/Accepted: 21 April 2014/Published online: 6 May 2014

(C) Islamic Azad University (IAU) 2014

\begin{abstract}
The effects of hydraulic retention time on the performance and microbial community structure of an anoxic-aerobic sequencing batch reactor treating saline wastewater were investigated. The average removal efficiencies of chemical oxygen demand and ammonia nitrogen decreased from 90 and $85 \%$ to 68 and $71 \%$ with the decrease in hydraulic retention time from 17 to $9 \mathrm{~h}$, respectively. No obvious accumulation of nitrate nitrogen and nitrite nitrogen in the effluent was found. The contents of polysaccharide and protein in extracellular polymeric substances increased with the decrease in hydraulic retention time. The polysaccharide/protein ratio decreased from 1.18 to 1.11 with the decrease in hydraulic retention time from 17 to $9 \mathrm{~h}$. The increase in extracellular polymeric substances with the decrease in hydraulic retention time led to the increase in sludge volume index. The specific ammonium oxidation rate, specific nitrite oxidation rate, specific nitrate reduction rate, and specific oxygen uptake rate increased with the decrease in hydraulic retention time. The diversity indices of microbial community decreased from 2.69 to 2.39 with the decrease in hydraulic retention time from 17 to $9 \mathrm{~h}$. The $\alpha$-proteobacteria were the dominant groups under hydraulic retention time of 17, 14, 11,
\end{abstract}

Z. C. Wang - M. C. Gao · Y. Ren - Z. L. She ·

C. J. Jin · J. Zhang $\cdot$ N. Yang

Key Lab of Marine Environment and Ecology,

Ministry of Education, Ocean University of China,

Qingdao 266100, People's Republic of China

M. C. Gao $(\varangle) \cdot$ Z. Wang · Q. B. Chang · C. Q. Sun

College of Environmental Science and Engineering, Ocean

University of China, No. 238 Songling Road, Qingdao 266100,

Shandong Province, People's Republic of China

e-mail: mengchungao@hotmail.com and $9 \mathrm{~h}$, which constituted 46, 30, 40, and $40 \%$ of the whole microbial community, respectively.

Keywords Hydraulic retention time - Sequencing batch reactor - Extracellular polymeric substances - Microbial activity $\cdot$ Microbial community structure

\section{Introduction}

The saline wastewaters are mainly derived from seafood processing, mariculture, oil production, cheese manufacturing, seawater for toilet flushing and industrial water, pharmaceutical process, and chemical production, which is rich in organic matter and nitrogen compound. When these saline wastewaters are discharged into the environment without prior treatment, they can cause severe damage by the contamination of soil, surface, and groundwater. The saline wastewaters are usually treated through physicochemical technology and biological treatment process. The physico-chemical technologies include evaporation, coagulation-flocculation, ion exchange, and membrane technology (Lefebvre and Moletta 2006). As the physicochemical technologies are generally energy-consuming, their startup and running costs are relatively high (Jang et al. 2013). Biological treatment processes have advantages over physico-chemical technology due to their low cost and high efficiency, and they have been widely used in removal of organic matter and nitrogen compound (Lefebvre and Moletta 2006). As the high salinity in the saline wastewaters can cause the plasmolysis, dehydration, disintegration of bacteria cell, and loss of cell activity, it results in the low removal efficiencies of organic matter and nitrogen (Dan et al. 2003; $\mathrm{Ng}$ et al. 2005). However, some biological processes have been satisfactorily employed in the 
treatment of saline wastewater by adapting non-halophilic microflora to hypersaline conditions (Panswad and Anan 1999; Campos et al. 2002; Gebauer 2004; Jang et al. 2013; Shi et al. 2012).

Sequencing batch reactor (SBR) is known to be particularly robust and to withstand extreme conditions, which incorporates alternating aerobic and anaerobic periods to achieve nitrification and denitrification, and it has often been employed to treat saline wastewater (Boopathy et al. 2007; Fontenot et al. 2007; Rene et al. 2008; Moussavi et al. 2010). The performance and microbial community of bioreactor can be affected by many influencing factors, such as nutrient content (Rene et al. 2008), anoxic/aerobic phase fraction (Hu et al. 2011), salinity (Fontenot et al. 2007), solid retention time (Moussa et al. 2005), and hydraulic retention time (HRT) (Kargi and Uygur 2003). Among the above-mentioned influencing factors, HRT is regarded as one of important operating parameters affecting the performance and microbial community of bioreactor (Wang et al. 2009). Li et al. (2013) investigated the effects of HRT on the nitrification activities and population dynamics of a conventional activated sludge system fed with synthetic inorganic wastewater, and they found that a short HRT strengthened the dominant position of the fastgrowing Nitrosomonas sp., which was responsible for the increase in the specific ammonium oxidation rate with the decrease in HRT. Lefebvre et al. (2005) reported that the removal efficiencies of chemical oxygen demand (COD) and total nitrogen in a SBR treating tannery soak liquor decreased from 95 and $96 \%$ to 92 and $54 \%$ with the decrease in HRT from 5 to 3.3 days at $34 \mathrm{~g} \mathrm{NaCl} / \mathrm{L}$, respectively. Durai et al. (2011) investigated the effect of HRT on the performance of SBR treating tannery wastewater by salt-tolerant bacterial strains, and they found that the COD removal efficiency significantly decreased with the decrease in HRT from 3 to 2 days. Muda et al. (2011) investigated the physical characteristics, microbial activities of the granular sludge from a SBR treating the synthetic textile wastewater under different HRTs, and they found that the HRT increase caused a decrease in biomass concentration, specific biomass growth rate, endogenous decay rate, and biomass yield. Zhang et al. (2006) evaluated the effects of HRT on the mixed anaerobic microbial community grown with glucose in a continuous stirred tank reactor. Han et al. (2010) reported the effects of HRT on the structure and function of sludge microbial community in a yeast-predominant activated sludge system for synthetic industrial wastewater. Although some researchers have reported the effect of HRT on the performance of some bioreactors, up to date and to our knowledge, little information has been found in investigating the effect of HRT on protein (PN) and polysaccharide (PS) in extracellular polymeric substances (EPS), microbial activity, and performance and microbial community of an anoxicaerobic SBR treating saline wastewater.

The major objectives of this study were (a) to investigate the effect of HRT on the performance of anoxicaerobic SBR treating saline wastewater; (b) to determine the effect of extracellular polymeric substances (EPS) on the sludge settleability under different HRTs; and (c) to analyze the effect of HRT on the microbial activity and community structure.

The study was carried out at the Key Lab of Marine Environmental Science and Ecology, Ministry of Education, Ocean University of China, Qingdao City, China, from September 2012 to January 2013.

\section{Materials and methods}

\section{Reactor setup and operation}

A lab-scale plexiglass anoxic-aerobic SBR with a working volume of 7.7 L was used under different HRTs. The SBR had an internal diameter of $14 \mathrm{~cm}$ and a total height of $55 \mathrm{~cm}$. A peristaltic pump was used to feed the influent into the reactor. The effluent was drawn at a height of $15 \mathrm{~cm}$ from the bottom by a solenoid valve, and the volume exchange rate every cycle was $70 \%$. The mixed liquor in the SBR at the anoxic stage was mixed by a magnetic stirrer (RH basic 1, IKA, Germany), and the air was introduced at the aerobic stage by two air diffusers at the bottom of the reactor.

The SBR cycles during different phases of operation are shown in Table 1 . The system was operated at room temperature $\left(20-30{ }^{\circ} \mathrm{C}\right)$. The dissolved oxygen (DO) concentration at the aerobic stage was above $2.0 \mathrm{mg} / \mathrm{L}$, and the DO concentration at the anoxic stage was below $0.5 \mathrm{mg} / \mathrm{L}$.

\section{Seed sludge and wastewater composition}

The seed sludge was obtained from a domesticated system treating $3 \%$ salinity wastewater in our laboratory. The initial mixed liquid suspended sludge (MLSS) in the SBR was $3500 \mathrm{mg} / \mathrm{L}$. The composition of synthetic saline wastewater was as follows $(\mathrm{mg} / \mathrm{L})$ : glucose, $384 ; \mathrm{NH}_{4} \mathrm{Cl}$, $60 ; \mathrm{Na}_{2} \mathrm{HPO}_{4}, 14$; and seawater crystal $3 \times 10^{4}$ (corresponding to the salinity of $3 \%$ ). According to the data provided by the sales company (Zhongyan Marine Science and Technology Co., Ltd. in Tianjin City, China), the main components of the seawater crystal solution at $3 \%$ salinity were provided as follows (mg/L): $\mathrm{Na}^{+}, 9,880 ; \mathrm{Cl}^{-}, 18,025$; $\mathrm{Mg}^{2+}, 950 ; \mathrm{SO}_{4}{ }^{2-}, 2,500 ; \mathrm{K}^{+}, 360 ; \mathrm{Ca}^{2+}, 300 ; \mathrm{Zn}^{2+}$, $1.5 \times 10^{-2} ; \mathrm{Mn}^{2+}, 1.3 \times 10^{-2} ; \mathrm{Fe}^{2+}, 1.3 \times 10^{-1} ; \mathrm{Co}^{2+}$, $3 \times 10^{-4} ; \mathrm{Mo}^{6+}, 3 \times 10^{-3} ; \mathrm{I}^{-}, 0.07 ; \mathrm{Sr}^{+}, 7.5 \times 10^{-3} ; \mathrm{I}^{-}$, $70 ; \mathrm{Se}^{6+}, 3.5 \times 10^{-4}$; and other inorganic ions. 
Table 1 Operation conditions of the SBR

\begin{tabular}{llllllll}
\hline HRT $(\mathrm{h})$ & Operational day $(\mathrm{d})$ & Cycle $(\mathrm{h})$ & Influent $(\mathrm{h})$ & Aerobic stage $(\mathrm{h})$ & Anoxic stage $(\mathrm{h})$ & Settling $(\mathrm{h})$ & Effluent withdrawal (h) \\
\hline 17 & $0-14$ & 12 & 0.25 & 7 & 3 & 1.5 & 0.25 \\
14 & $15-41$ & 10 & 0.25 & 5.6 & 2.4 & 1.5 & 0.25 \\
11 & $42-56$ & 8 & 0.25 & 4.2 & 1.8 & 1.5 & 0.25 \\
9 & $57-96$ & 6 & 0.25 & 2.8 & 1.2 & 1.5 & 0.25 \\
\hline
\end{tabular}

Analytical methods

The measurements of COD, ammonia nitrogen $\left(\mathrm{NH}_{4}{ }^{+}-\mathrm{N}\right)$, nitrite nitrogen $\left(\mathrm{NO}_{2}{ }^{-}-\mathrm{N}\right)$, nitrate nitrogen $\left(\mathrm{NO}_{3}{ }^{-}-\mathrm{N}\right)$, mixed liquor volatile suspended solids (MLVSS), mixed liquor suspended solids (MLSS), and sludge volume index (SVI) were carried out according to the Chinese NEPA standard methods (Chinese NEPA 2002). The dissolved oxygen (DO) concentration in the reactor was measured by a dissolved oxygen meter (oxi 330i, WTW, Germany). The EPS of the sludge samples were extracted by a thermal extraction (Chang and Lee 1998). The protein (PN) in the EPS extractions was measured by the method of Lowery et al. (1951) with bovine serum albumin as the standard. The polysaccharide (PS) in the EPS extractions was determined as glucose equivalents using the anthrone-sulfuric acid method (Dubois et al. 1956).

The determination of specific oxygen utilization rate (SOUR)

A certain amount of activated sludge from the SBR was transferred into a pre-cleaned BOD bottle. The BOD bottle was fully filled in with the pre-aerated mineral medium which had the same composition as synthetic wastewater. The mineral medium was pre-aerated in order to keep the DO concentration above $8.0 \mathrm{mg} / \mathrm{L}$ for $10 \mathrm{~min}$. And then, the rubber stopper was firmly pressed down the BOD bottle. An oxygen-sensing probe passed through the rubber stopper was inserted into the BOD bottle, and the DO concentration was recorded at an interval of $30 \mathrm{~s}$ until the DO concentration below $1.0 \mathrm{mg} / \mathrm{L}$. MLSS was determined at the end of batch experiment. The SOUR was calculated from DO-time curve based on the concentration of activated sludge in the BOD bottle. The mixed liquor in the BOD bottle was mixed by a magnetic stirrer (RH basic 1, IKA, Germany), and the SOUR test was conducted at room temperature.

The determinations of specific ammonium oxidation rate (SAOR), specific nitrite oxidation rate (SNOR), and specific nitrate reduction rate (SNRR)

The SAOR, SNOR, and SNRR were determined by batch experiments. In the SAOR (or SNOR) determination, batch experiment was performed in a 500-mL Erlenmeyer flask with $100 \mathrm{~mL}$ activated sludge from SBR and $400 \mathrm{~mL}$ mineral medium at room temperature. The mixed liquor in the Erlenmeyer flask was mixed by a magnetic stirrer (RH basic 1, IKA, Germany), and the air was introduced by an air diffuser (ACO-002, Zhejiang Sensen Industrial Co., Ltd., China). The composition of mineral medium for the determination of SAOR (or SNOR) was as follows (mg/L): $\mathrm{NH}_{4} \mathrm{Cl}, 120$ (or $\mathrm{NaNO}_{2}, 147$ ); $\mathrm{Na}_{2} \mathrm{HPO}_{4}, 14$; and seawater crystal $3 \times 10^{4}$ (corresponding to the salinity $3 \%$ ). Sample was taken at an interval of $15 \mathrm{~min}$ to analyze the concentrations of $\mathrm{NH}_{4}{ }^{+}-$ $\mathrm{N}$ (or $\mathrm{NO}_{2}{ }^{-}-\mathrm{N}$ ), and MLSS was determined at the end of batch experiment. The ammonium oxidation rate (or nitrite oxidation rate) was calculated from the slope of the linear progression curve of $\mathrm{NH}_{4}{ }^{+}-\mathrm{N}$ (or $\mathrm{NO}_{2}{ }^{-}-\mathrm{N}$ ) versus time, and the SAOR (or SNOR) was calculated from the ratio of ammonium oxidation rate (or nitrite oxidation rate) and MLSS.

In the SNRR determination, batch experiment was performed in a 500-mL Erlenmeyer flask with $100 \mathrm{~mL}$ activated sludge from the SBR and $400 \mathrm{~mL}$ mineral medium at room temperature. The mixed liquor in the Erlenmeyer flask was mixed by a magnetic stirrer (RH basic 1, IKA, Germany), and anaerobic environment was obtained by introducing nitrogen gas continuously through a gas diffuser. The composition of mineral medium for the determination of SNRR was as follows $(\mathrm{mg} / \mathrm{L})$ : glucose, 640; $\mathrm{NaNO}_{3}, 303 ; \mathrm{Na}_{2} \mathrm{HPO}_{4}, 14$; and seawater crystal $3 \times 10^{4}$ (corresponding to the salinity $3 \%$ ). Sample was taken at an interval of $15 \mathrm{~min}$ to analyze the concentrations of $\mathrm{NO}_{3}{ }^{-}$$\mathrm{N}$, and MLSS was determined at the end of batch experiment. The nitrate reduction rate was calculated from the slope of the linear progression curve of $\mathrm{NO}_{3}{ }^{-}-\mathrm{N}$ versus time, and the SNRR was calculated from the ratio of nitrate reduction rate and MLSS.

PCR-DGGE and sequence analysis

\section{DNA extraction}

The DNA was extracted from $0.25 \mathrm{~g}$ (dry weight) activated sludge using PowerSoil ${ }^{\circledR}$ DNA Islation Kit (Anbisheng Inc., China) according to the manufacturer's protocol. 


\section{PCR amplification}

PCR amplifications were carried out in an iCycler Thermal Cycler PCR (Bio-Rad Co., Ltd., USA). The bacterial primer $101 \mathrm{~F}$ with a GC clamp (5'-CGCCCGCCGCGCGCGGCG GGCGGGGCGGGGGCACGGGGGGTGGCGGACGGGT GAGTAA- $\left.3^{\prime}\right)$ and the universal primer $534 \mathrm{R}\left(5^{\prime}\right.$-ATT ACC GCG GCT GCT GG-3'), targeting the 16S rRNA V3 variable region, were used to amplify 16S rDNA (Muyzer et al. 1993). The $50 \mu \mathrm{L}$ reaction mixture contained $2 \mu \mathrm{L}$ extracted DNA template, $0.5 \mu \mathrm{L}$ TaKaRa Taq ${ }^{\mathrm{TM}}$ DNA polymerase $(5 \mathrm{U} / \mu \mathrm{L}$, TaKaRa Biotechnology Dalian Co. Ltd., China), $5 \mu \mathrm{L}$ $10 \times$ PCR buffer $\left(\mathrm{Mg}^{2+}\right.$ plus, TaKaRa Biotechnology Dalian Co. Ltd., China), $4 \mu \mathrm{L}$ dNTP (each $2.5 \mathrm{mmol} / \mathrm{L}$ ), $1 \mu \mathrm{L}$ each primer (each $20 \mu \mathrm{mol} / \mathrm{L}$, TaKaRa Biotechnology Dalian Co. Ltd., China), and adjusted to a final volume of $50 \mu \mathrm{L}$ with sterile deionized water. The PCR amplification of $16 \mathrm{~S}$ rDNA was performed according to the Touchdown PCR program (Muyzer et al. 1993): initial denaturation at $95{ }^{\circ} \mathrm{C}$ for $5 \mathrm{~min}$, denaturation at $95{ }^{\circ} \mathrm{C}$ for $30 \mathrm{~s}$, annealing at $56{ }^{\circ} \mathrm{C}$ for $30 \mathrm{~s}$ (the temperature was decreased by $0.5^{\circ} \mathrm{C}$ every cycle until the touchdown temperature of $51{ }^{\circ} \mathrm{C}$ was reached), extension at $72{ }^{\circ} \mathrm{C}$ for $45 \mathrm{~s}$, denaturation at $95{ }^{\circ} \mathrm{C}$ for $30 \mathrm{~s}$ after 10 cycles, annealing at $51{ }^{\circ} \mathrm{C}$ for $30 \mathrm{~s}$, extension at $72{ }^{\circ} \mathrm{C}$ for $45 \mathrm{~s}$ followed by a final extension at $72{ }^{\circ} \mathrm{C}$ for $10 \mathrm{~min}$ after 20 cycles, and end at $4{ }^{\circ} \mathrm{C}$. The PCR products stained with ethidium bromide (EB) were electrophoresed in a $1.2 \%(\mathrm{w} / \mathrm{v})$ agarose gel at $120 \mathrm{~V}$ for $40 \mathrm{~min}$, and quantified by comparison with a standard marker (DL 2000, TaKaRa Biotechnology Dalian Co. Ltd., China).

\section{DGGE analysis}

DGGE was performed using a DCode ${ }^{\mathrm{TM}}$ Universal Mutation Detection System (Bio-Rad Co., Ltd., USA). PCR samples containing $40 \mu \mathrm{L}$ PCR amplification products and $8 \mu \mathrm{L} 6 \times$ Loading buffer were loaded into each well of a $8 \%(\mathrm{w} / \mathrm{v}, \mathrm{g} / \mathrm{mL})$ polyacrylamide (37.5:1, acrylamide : bisacrylamide) gel in $1 \times$ TAE buffer (Tris-acetate-EDTA buffer) using a denaturing gradient ranging from 30 to $60 \%$ (30\% denaturant agent contained $2.52 \mathrm{~g}$ urea, $2.4 \mathrm{~mL}$ deionized formamide, $4.0 \mathrm{~mL} 40 \%$ polyacrylamide, $0.4 \mathrm{~mL} 50 \times$ TAE buffer and adjusted to a final volume of $20.0 \mathrm{~mL}$ with deionized water; the content of each component for $60 \%$ denaturant agent was twice of the $30 \%$ ). Electrophoreses were performed at $65^{\circ} \mathrm{C}$ and $150 \mathrm{~V}$ for $420 \mathrm{~min}$. After electrophoresis, the gel was stained with $0.1 \% \mathrm{AgNO}_{3}$ for $25 \mathrm{~min}$ and then rinsed with Milli-Q water. The gels were visualized under UV light with the Gel Doc XR System (Bio-Rad Co., Ltd., USA).

DGGE profiles were analyzed using the Quantity One software (version 4.6.2, Bio-Rad Co., Ltd., USA).
Dendrograms relating band pattern similarities were automatically calculated using the unweighted pair group method with the arithmetic average (UPGMA) clustering algorithm, which was included in the Quantity One software. The diversity of microbial community was examined by the Shannon diversity index $(H)$ (Shannon and Weaver 1949). $H$ was calculated on the basis of the bands on the gel tracks that were applied for the generation of the dendrograms by using the intensities of the bands as judged by peak heights in the densitometric curves. The equation for the Shannon diversity index is as follows:

$H=-\sum\left(n_{i} / N\right) \log \left(n_{i} / N\right)$

where $n_{i}$ is the height of the peak and $\mathrm{N}$ the sum of all peak heights of the densitometric curve.

\section{Sequence analysis}

The DGGE bands were excised from the gel, re-amplified, and electrophoresed again in DGGE gel to confirm the mobility of the bands. The new PCR products were cloned. The cloned products were sequenced by Shanghai Jinsirui Biological Science and Technology Co., Ltd. Bacteria serial numbers were obtained from ribosomal database project (http://rdp.cme.msu.edu/). Sequence comparisons were conducted with the BLAST search option in the NCBI nucleotide sequence database (http://www.ncbi.nlm. nih.gov/). A phylogenetic tree was constructed using the neighbor-joining method by the software MEGA 4.0 (Saitou and Nei 1987; Kumar et al. 2004), and reference sequences used in tree construction were acquired from GenBank. The bootstrap analysis was performed on the basis of 1,000 bootstrap replications (Felsenstein 1985). The sequences obtained in this study were submitted to the

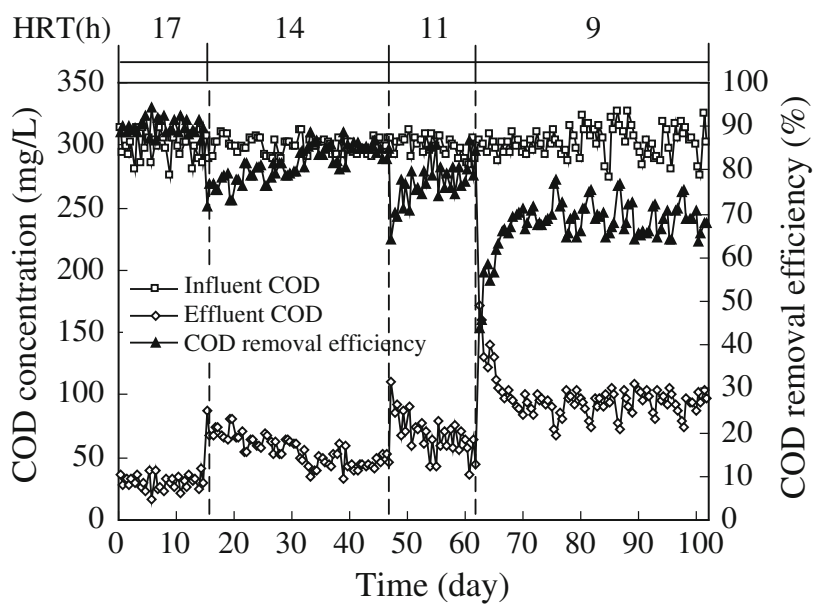

Fig. 1 Variations of influent and effluent COD concentrations under different HRTs 
DDBJ database under accession numbers AB896738AB896757.

\section{Results and discussion}

\section{Effect of HRT on COD removal}

The time courses of COD removal efficiency under different HRTs are shown in Fig. 1. The average COD removal efficiencies gradually decreased from 90 to $68 \%$ with the decrease in HRT from 17 to $9 \mathrm{~h}$ at steady states. It is clear that the shorter HRTs operated the lower removal efficiencies of COD achieved. As the influent COD concentrations varied in the range of 274 and $327 \mathrm{mg} / \mathrm{L}$ during the whole operational period, the average organic loading rates (OLR) under HRTs of $17,14,11$, and $9 \mathrm{~h}$ corresponded to $0.42,0.51,0.65$, and $0.80 \mathrm{~kg} \mathrm{COD} /\left(\mathrm{m}^{3}\right.$ day $)$, respectively. The decrease in COD removal efficiency could be related to the shorter contact time between the activated sludge and organic matter. Kapdan (2005) reported the similar results that the COD removal efficiency decreased with the increase in OLR in an anaerobic packed column reactor treating synthetic dyestuff wastewater. In addition, the decrease in COD removal efficiency might also be due to the fact that some bacteria were washed out from the SBR when the HRT was less than facultative bacteria generation time. Yang et al. (2006) illustrated that some bacteria were washed out of UASB while the HRT was less than $12 \mathrm{~h}$, and the COD removal efficiency decreased with the decrease in HRT.

\section{Effect of HRT on nitrogen removal}

The time courses of $\mathrm{NH}_{4}^{+}-\mathrm{N}, \mathrm{NO}_{3}{ }^{-}-\mathrm{N}$, and $\mathrm{NO}_{2}{ }^{-}-\mathrm{N}$ concentrations in the influent and effluent under different HRTs are shown in Fig. 2. The average $\mathrm{NH}_{4}{ }^{+}-\mathrm{N}$ removal efficiency at steady state decreased from 85 to $71 \%$ with the decrease in HRT from 17 to $9 \mathrm{~h}$. The average $\mathrm{NH}_{4}{ }^{+}-\mathrm{N}$ loading rate increased with the decrease in HRT, which lead to the decrease in $\mathrm{NH}_{4}{ }^{+}-\mathrm{N}$ removal efficiency in the aerobic-anoxic SBR treating saline wastewater. Compared to heterotrophic bacteria, the growth of ammonia-oxidizing bacteria was relatively slow (Isaka et al. 2013). The lower growth rate of ammonia-oxidizing bacteria led to the decrease in the proportion of ammonia-oxidizing bacteria among the total bacteria with the decrease in HRT (Li et al. 2013). The effluent concentrations of $\mathrm{NO}_{2}{ }^{-}-\mathrm{N}$ and $\mathrm{NO}_{3}{ }^{-}-\mathrm{N}$ were less than $0.4 \mathrm{mg} / \mathrm{L}$ during the whole operation time (Fig. 2b, c). No obvious variations of $\mathrm{NO}_{2}{ }^{-}-\mathrm{N}$ and $\mathrm{NO}_{3}{ }^{-} \mathrm{N}$ in effluent were found under different HRT, which indicated that the denitrification process was not influenced by the decrease in HRT.
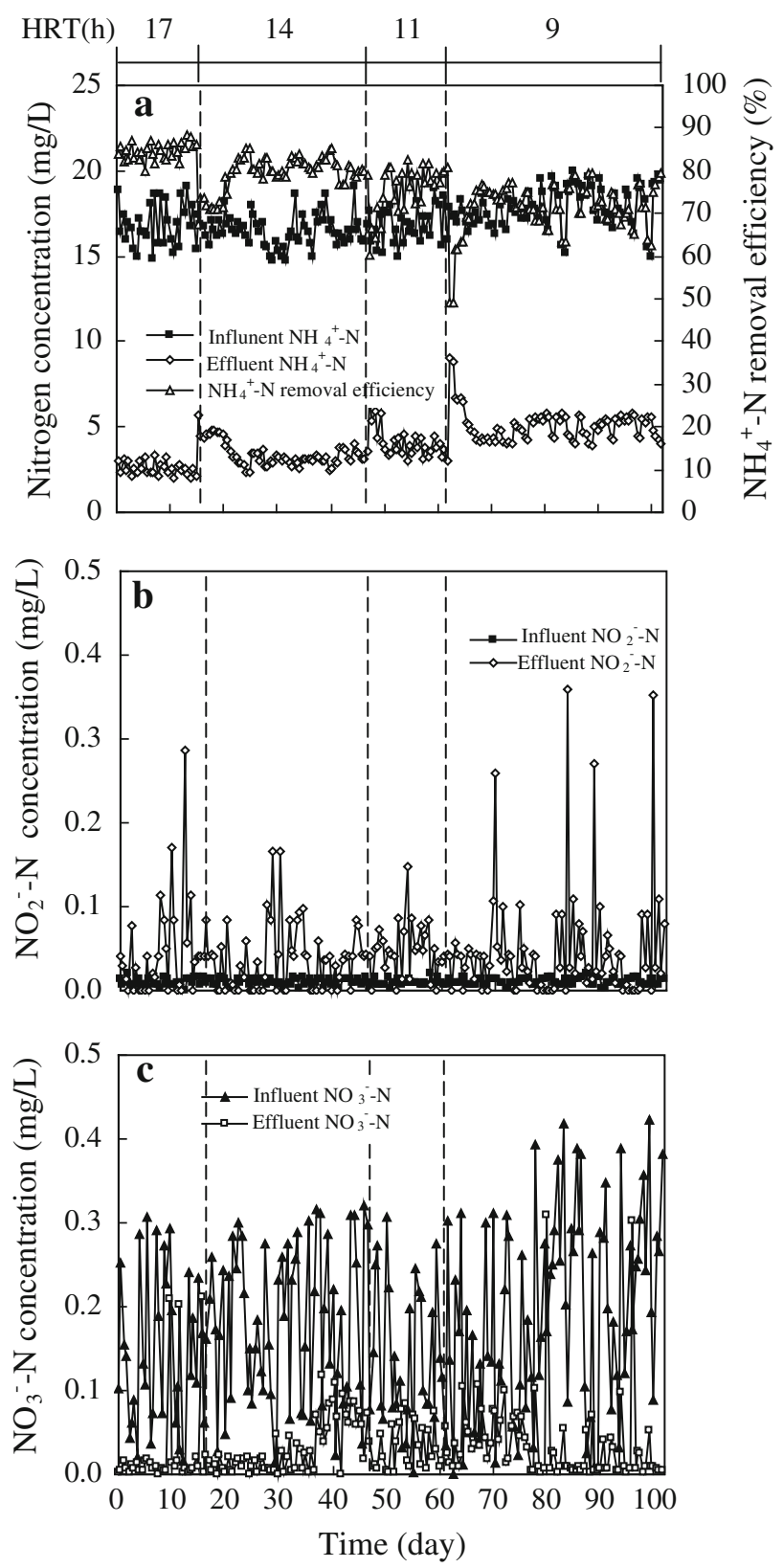

Fig. 2 Variations of influent and effluent concentrations of $\mathrm{NH}_{4}{ }^{+}-\mathrm{N}$ (a), $\mathrm{NO}_{2}{ }^{-}-\mathrm{N}(\mathbf{b})$, and $\mathrm{NO}_{3}{ }^{-}-\mathrm{N}$ (c) under different HRTs

Relationship between EPS and sludge settleability under different HRTs

EPS are secreted by microorganisms in biological wastewater treatment systems, and the variations of production and composition of EPS have significant influences on the physico-chemical properties of microbial aggregates $(\mathrm{Li}$ and Yang 2007). In order to characterize the relationship between EPS and sludge settleability, the sludge sample at steady state conditions were obtained from the anoxicaerobic SBR on day 13, 40, 55, and 95, corresponding to 


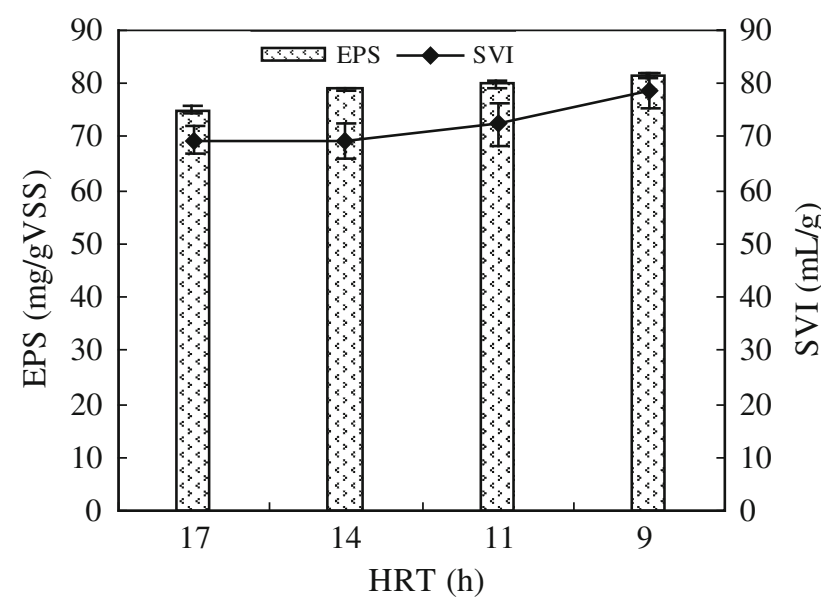

Fig. 3 Variations of EPS and SVI under different HRTs

HRT of 17, 14, 11, and $9 \mathrm{~h}$, respectively. As shown in Fig. 3, the EPS content increased from 75.1 to $81.5 \mathrm{mg} / \mathrm{g}$ VSS with the decrease in HRT from 17 to $9 \mathrm{~h}$. The contact time between the microbes and organic matter was relatively sufficient at the longer HRT, which can lead to the nutrient lack in the anoxic-aerobic SBR. Zhang and Bishop (2001) reported that the part of EPS could be utilized by the microbes as carbon or energy sources under the conditions of nutrient lack. Park et al. (2004) illustrated that the EPS content at the long HRT was less than that at the short HRT. Similarly, the SVI contents increased from 69 to $79 \mathrm{~mL} / \mathrm{g}$ with the decrease in HRT from 17 to $9 \mathrm{~h}$. As the EPS have significant influences on the physico-chemical properties of microbial aggregates in the bioreactor, the variations of SVI content under different HRTs are related to the variation of EPS in the SBR. The EPS exhibit a dynamic double-layered structure, and the outer layer contained a large amount of bound water (Zhang et al. 2011). The increase in EPS content resulted in the increase in bound water in activated sludge flocs, which decreased the performance of sludge sedimentation. Many previous researches reported that the increase in EPS content could lead to the increase in SVI ( $\mathrm{Li}$ and Yang 2007; Park et al. 2004). In addition, as there are many charged functional groups in EPS, their content and composition influence the surface charge of microbial aggregates (Sheng et al. 2010), which also resulted in a decrease in the settleability of microbial aggregates.

The variations of PN and PS contents in the EPS under different HRTs are shown in Fig. 4. The PN and PS contents in EPS increased from 40.7 and $34.4 \mathrm{mg} / \mathrm{g}$ VSS on day 13 to 43.0 and $39.0 \mathrm{mg} / \mathrm{g}$ VSS on day 95 with the decrease in HRT from 17 to $9 \mathrm{~h}$, respectively (Fig. 4a). The results suggested that the decrease in HRT stimulated the microorganisms to produce more PN and PS in the EPS, which was consistent with the previous research that PN and PS contents in the bound EPS at the long HRT were
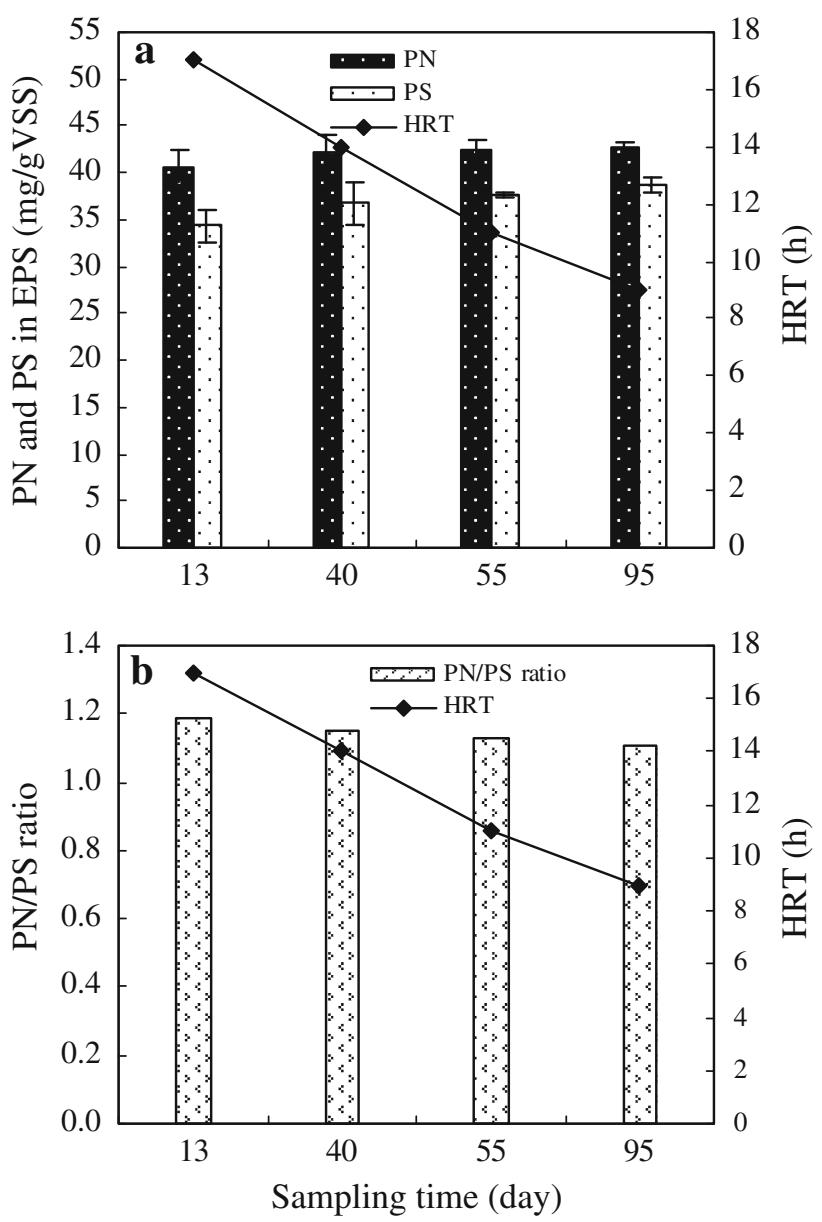

Fig. 4 Variations of production and composition in EPS under different HRTs. a PN and PS; b PN/PS ratio

less than those at the short HRT (Park et al. 2004). The PN and PS contents in the EPS were increased by 5 and $13 \%$ with the decrease in HRT from 17 to $9 \mathrm{~h}$, respectively, suggesting that PS in the EPS was more sensitive to the variation of HRT. The PN/PS ratios in the EPS gradually decreased from 1.18 to 1.11 with the decrease in HRT from 17 to 9 (Fig. 4b). As the PN in the EPS was hydrophobic, the low PN/PS in EPS reduced cell surface hydrophobicity, which decreased the flocculating ability of sludge. The low flocculating ability of sludge was not beneficial to the settling of sludge. Chen et al. (2010) reported similar results that lower PN/PS ratio in EPS could produce poor sludge settleability.

\section{Effect of HRT on microbial activity}

The SOUR of the sludge from the anoxic-aerobic SBR were investigated on day $13,40,55$, and 95 , corresponding to HRT of $17,14,11$, and $9 \mathrm{~h}$, respectively. As shown in Fig. 5a, the SOUR increased from 39 to $44 \mathrm{mg} \mathrm{O} /(\mathrm{g} \mathrm{MLSS} \mathrm{h})$ with the decrease in HRT from 

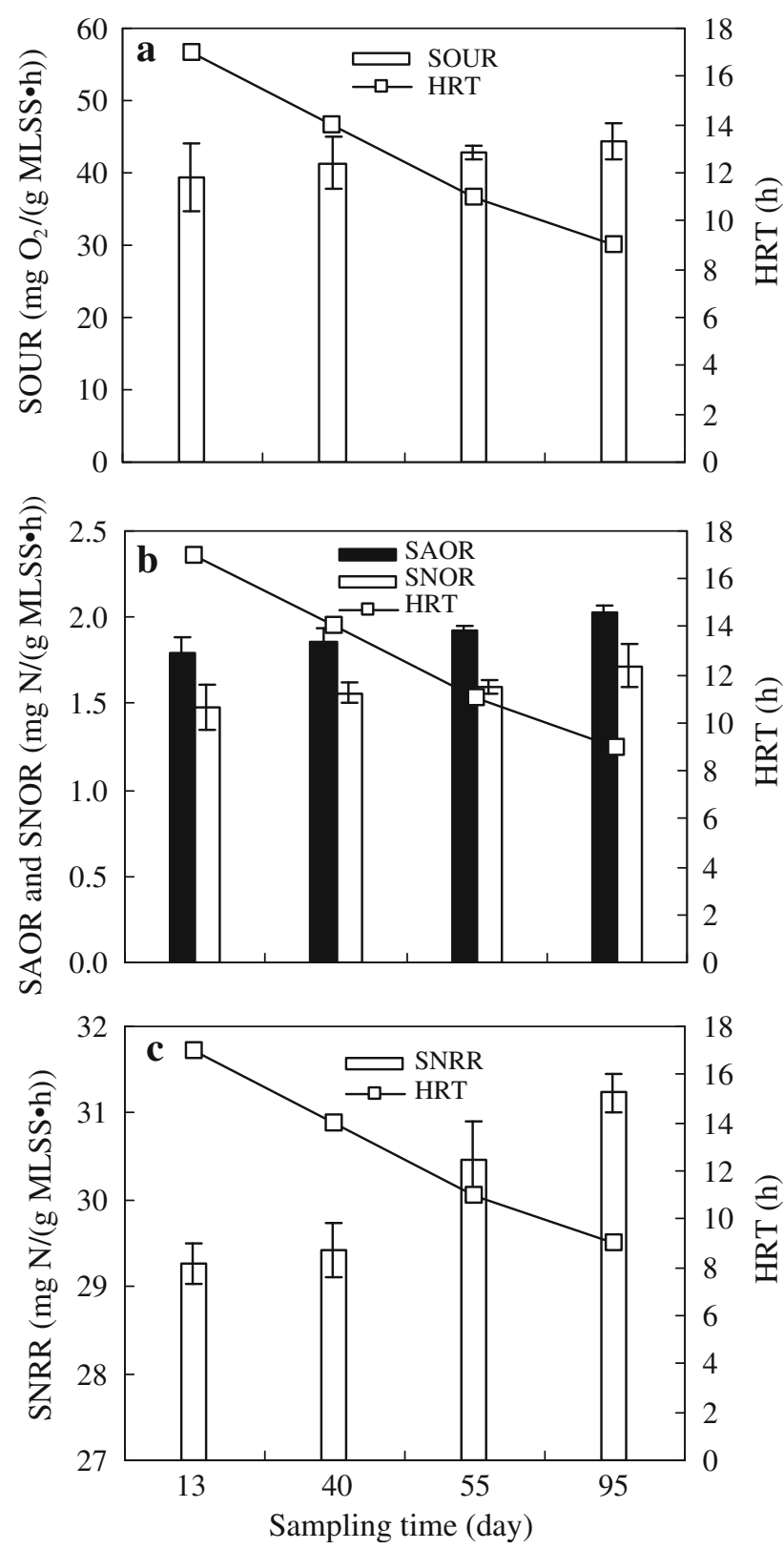

Fig. 5 Variations of SOUR (a), SAOR, SNOR (b), and SNRR (c) under different HRTs

17 to $9 \mathrm{~h}$, which can be explained that more carbonaceous substrate was provided to bacteria at short HRT and led to an increase in SOUR values. Barr et al. (1996) reported the similar results that the SOUR values increased with the decrease in HRT in an activated sludge reactor treating bleached kraft mill effluent. Fig. 5b shows the variations of SAOR and SNOR under different HRTs. The SAOR and SNOR increased from 1.79 and $1.48 \mathrm{mg} \mathrm{N} /(\mathrm{g}$ MLSS h) to 2.0 and $1.7 \mathrm{mg} \mathrm{N} /(\mathrm{g}$ MLSS h) with the decrease in HRT from 17 to $9 \mathrm{~h}$. The $\mathrm{NH}_{4}{ }^{+}-\mathrm{N}$ loading rate in the SBR increased with the decrease in HRT, which resulted the increase in the
SAOR and SNOR. Hwang et al. (2009) reported that the specific nitrification rate increased linearly with the specific $\mathrm{NH}_{4}{ }^{+}-\mathrm{N}$ loading rate in a SBR. As shown in Fig. 5c, the SNRR increased from 29.3 to $31.2 \mathrm{mg} \mathrm{N} /(\mathrm{g}$ MLSS h) with the decrease in HRT from 17 to $9 \mathrm{~h}$. Kim et al. (2008) found that average specific denitrification rate increased from 15.0 to $48.0 \mathrm{mg} \mathrm{N} /(\mathrm{g}$ MLSS h) with the decrease in HRT from 24.9 to $7.9 \mathrm{~h}$ in the biological pre-denitrification process for the simultaneous removal of toxic pollutants from cokes wastewater.

Effect of HRT on microbial community structure

The microbial community structures of the anoxic-aerobic SBR under different HRTs were investigated through PCR-DGGE analysis. As shown in Fig. 6a, the DGGE analysis showed that there were some changes in the band profile with the decrease in the HRT from 17 to $9 \mathrm{~h}$ as well as the variations in band intensity. Some bands $(5,8-11$, and 18) were observed in all the samples under different HRTs, and their variations were found in the band intensity. The other bands (1-4, 6, 7, 12-17, 19, and 20) appeared under different HRTs, and they were not necessarily present throughout the whole operational period. It is evident that some microbes adapting to HRT variation tend to become predominant bacteria, while others tend to deplete or gradually weaken. The UPGMA clustering analysis was used to analyze the microbial community similarities under different HRTs. Figure $6 \mathrm{~b}$ shows that the microbial populations were categorized into separate groups. The first group represented the sludge sample under $17 \mathrm{~h}$ HRT, and the second group was sub-categorized into two groups. The similarity of microbial community between the first group and the second group was less than $30 \%$, which indicated that the decrease in HRT had a significant effect on the microbial community structure. The diversity indices of microbial community decreased from 2.62 to 2.29 with the decrease in hydraulic retention time from 17 to $9 \mathrm{~h}$, indicating low microbial diversity in the aerobic-anoxic SBR treating saline wastewater at short HRT.

To gain further insight into the microbial community structure, twenty discernable bands were excised from the DGGE gel and sequenced, and the accurate sequencing of bands 6,7 , and 9 were not available. By using the BLAST program of GenBank, the detected sequences were compared with sequences deposited in the database. The most similar sequences of discernable DGGE bands are listed in Table 2. Methylobacillus flagellatus (band 8), Terrimonas lutea (band 10), and Paracoccus homiensis (band 11) were present in all the samples, which were proved that they could utilize 


\section{a}

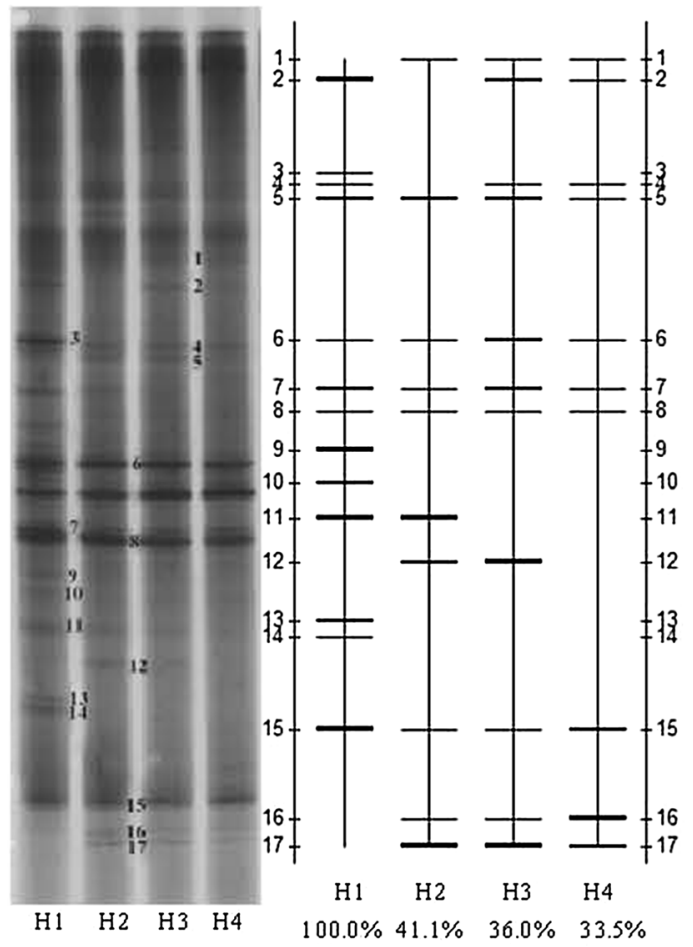

b

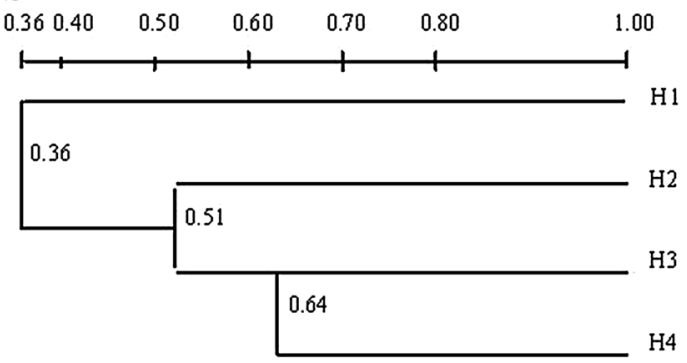

c

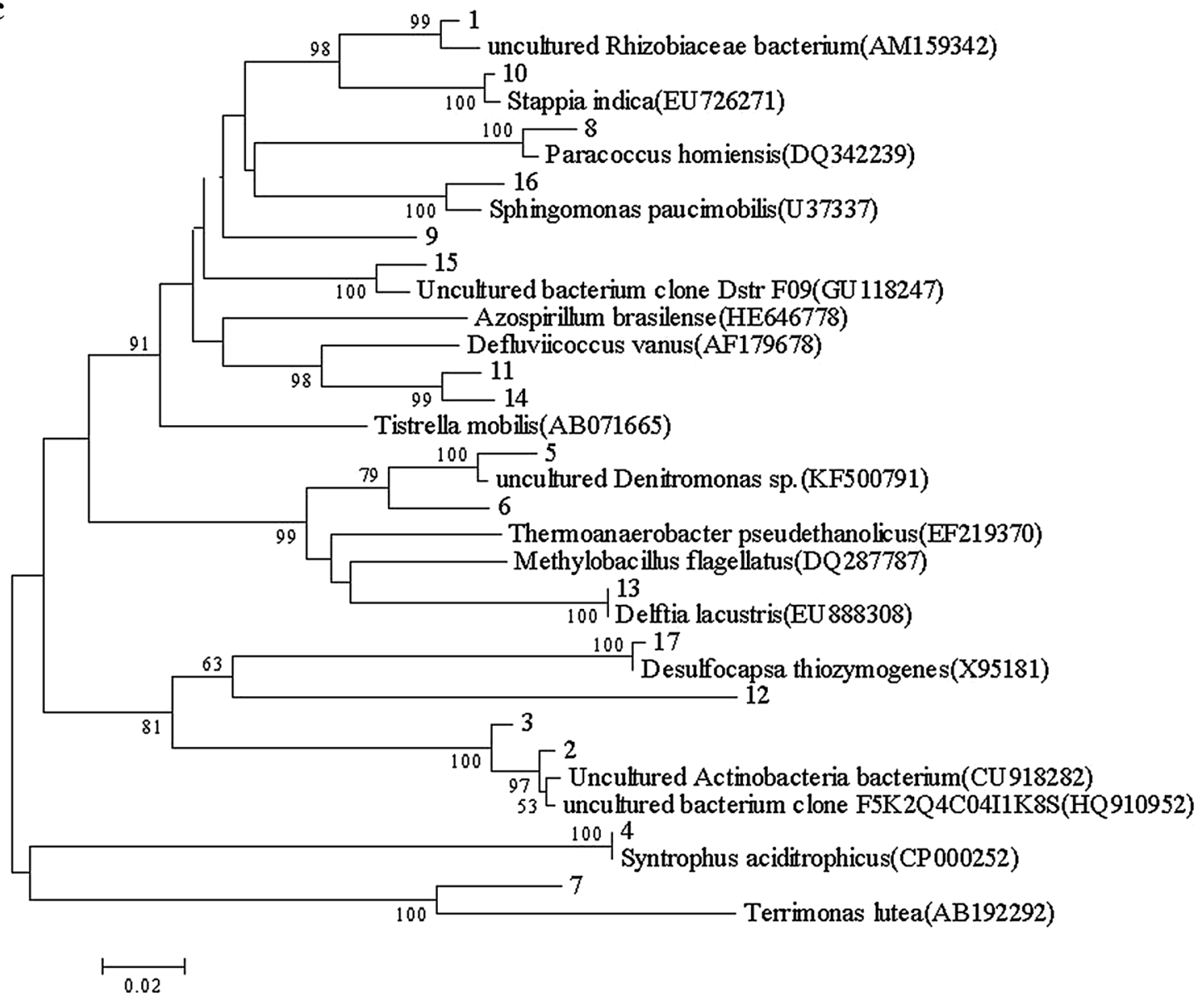


4Fig. 6 Analysis of microbial populations under different HRTs. a DGGE gel banding profiles of microbial communities in the aerobic-anoxic SBR under different HRTs. H1: HRT $=17 \mathrm{~h} ; \mathrm{H} 2$ : HRT $=14 \mathrm{~h}$; H3: HRT $=11 \mathrm{~h} ; \mathrm{H} 4:$ HRT $=9 \mathrm{~h}$. b Percent similarity analysis of lanes on the DGGE gel. c Phylogenetic tree of bacteria based on the results of BLAST. The phylogenetic tree was constructed using the neighbor-joining method. The numbers at the nodes are bootstrap confidence values expressed as percentages of 1,000 bootstrap replications. Bootstrap values less than $50 \%$ are not shown glucose as organic substrate (Chistoserdova et al. 2007; Xie and Yokota 2006; Kim et al. 2006). The results suggest that these bacteria species could adapt to the HRT variation in the anoxic-aerobic SBR treating saline wastewater. The bands 12, 13, 16, and 17 were related to Defluviicoccus vanus, Stappia indica, Delftia lacustris, and Azospirillum brasilense, respectively, and they appeared at $17 \mathrm{~h}$ HRT and then disappeared with

Table 2 Closest phylogenetic affiliations of sequences obtained from sludge samples at different HRTs

\begin{tabular}{|c|c|c|c|c|}
\hline Bands & $\begin{array}{l}\text { Closest related sequences } \\
\left(\text { Accession number }{ }^{\mathrm{a}}\right)\end{array}$ & Accession number ${ }^{\mathrm{b}}$ & Similarity $(\%)$ & Class containing related sequences \\
\hline 1 & $\begin{array}{l}\text { uncultured Rhizobiaceae bacterium } \\
\text { AM159342 }\end{array}$ & AB896738 & 97 & $\alpha$-proteobacteria \\
\hline 2 & $\begin{array}{l}\text { Uncultured Actinobacteria bacterium } \\
\text { CU918282 }\end{array}$ & AB896739 & 98 & _ \\
\hline 3 & $\begin{array}{l}\text { uncultured bacterium clone F5K2Q4C04I1K8S } \\
\text { GU912285 }\end{array}$ & AB896740 & 97 & - \\
\hline 4 & $\begin{array}{l}\text { Syntrophus aciditrophicus } \\
\text { CP000252 }\end{array}$ & AB896741 & 98 & $\delta$-proteobacteria \\
\hline 5 & $\begin{array}{l}\text { uncultured Denitromonas sp. } \\
\text { KF500791 }\end{array}$ & AB896742 & 98 & $\beta$-proteobacteria \\
\hline 8 & $\begin{array}{l}\text { Methylobacillus flagellatus } \\
\text { DQ287787 }\end{array}$ & AB896745 & 99 & $\beta$-proteobacteria \\
\hline 10 & $\begin{array}{l}\text { Terrimonas lutea } \\
\text { AB192292 }\end{array}$ & AB896747 & 100 & $\varepsilon$-proteobacteria \\
\hline 11 & $\begin{array}{l}\text { Paracoccus homiensis } \\
\text { DQ342239 }\end{array}$ & AB896748 & 98 & $\alpha$-proteobacteria \\
\hline 12 & $\begin{array}{l}\text { Defluviicoccus vanus } \\
\text { AF179678 }\end{array}$ & AB896749 & 99 & $\alpha$-proteobacteria \\
\hline 13 & $\begin{array}{l}\text { Stappia indica } \\
\text { EU726271 }\end{array}$ & AB896750 & 99 & $\alpha$-proteobacteria \\
\hline 14 & $\begin{array}{l}\text { Tistrella mobilis } \\
\text { AB071665 }\end{array}$ & AB896751 & 100 & $\alpha$-proteobacteria \\
\hline 15 & $\begin{array}{l}\text { Thermoanaerobacter pseudethanolicus } \\
\text { EF219370 }\end{array}$ & AB896752 & 100 & Clostridia \\
\hline 16 & $\begin{array}{l}\text { Delftia lacustris } \\
\text { EU888308 }\end{array}$ & AB896753 & 100 & $\beta$-proteobacteria \\
\hline 17 & $\begin{array}{l}\text { Azospirillum brasilense } \\
\text { HE } 646778\end{array}$ & AB896754 & 100 & $\alpha$-proteobacteria \\
\hline 18 & $\begin{array}{l}\text { Uncultured bacterium clone Dstr_F09 } \\
\text { GU118247 }\end{array}$ & AB896755 & 97 & - \\
\hline 19 & $\begin{array}{l}\text { Sphingomonas paucimobilis } \\
\text { U37337 }\end{array}$ & AB896756 & 98 & $\alpha$-proteobacteria \\
\hline 20 & $\begin{array}{l}\text { Desulfocapsa thiozymogenes } \\
\text { X95181 }\end{array}$ & AB896757 & 98 & $\delta$-proteobacteria \\
\hline
\end{tabular}

Accurate sequencing of bands 6,7 , and 9 were not available

${ }^{a}$ The accession numbers were obtained from ribosomal database project

b The accession numbers were obtained from the DDBJ database 
the decrease in HRT. Defluviicoccus vanus was able to reduce nitrate but most likely unable to reduce nitrite (Wang et al. 2008). Stappia indica was moderately halophilic bacteria and could reduce nitrate (Lai et al. 2010). Delftia lacustris could utilize D-glucose as energy and carbon sources, and reduce nitrate (Jørgensen et al. 2009). The sequence of band 17 was $100 \%$ similar to Azospirillum brasilense, which was capable of removing ammonium and phosphorous ions in wastewater (de-Bashan et al. 2002). The disappearance of Azospirillum brasilense might result in the significant decrease in the removal efficiencies of $\mathrm{NH}_{4}{ }^{+}-\mathrm{N}$ with the reduction in HRT. As Sphingomonas paucimobilis (band 19) and Desulfocapsa thiozymogenes (band 20) did not appear at $17 \mathrm{~h}$ HRT, they appear between 14 and 9 h HRT. Sphingomonas paucimobilis was identified as denitrifying bacterium (Jørgensen and Pauli 1995), which could explain why no obvious accumulation of $\mathrm{NO}_{2}{ }^{-}-\mathrm{N}$ and $\mathrm{NO}_{3}{ }^{-}-\mathrm{N}$ was found during the whole operational period. Syntrophus aciditrophicus (band 4) appeared at the HRT of 17,14 , and $9 \mathrm{~h}$, but they disappeared at the HRT of $11 \mathrm{~h}$. Tistrella mobilis (band 14) was only found at the HRT of 17 and $11 \mathrm{~h}$, and Thermoanaerobacter pseudethanolicus (band 15) appeared at the HRT of 14 and $11 \mathrm{~h}$. Tistrella mobilis could reduce nitrate to nitrite but not to nitrogen (Shi et al. 2002). Thermoanaerobacter pseudethanolicus could have the capability to ferment glucose (Onyenwoke et al. 2007).

The phylogenic tree based on DGGE profiles is shown in Fig. 6c. The $\alpha$-proteobacteria were the dominant groups under HRT of 17, 14, 11, and $9 \mathrm{~h}$, which constituted 46, 30, 40 , and $40 \%$ of the whole microbial community, respectively. The $\beta$-proteobacteria were the next groups constituting $23,20,20$, and $20 \%$ under HRT of 17, 14, 11, and $9 \mathrm{~h}$, respectively. Although the anoxic-aerobic SBR under different HRTs had the same dominant groups, such as $\alpha$ proteobacteria and $\beta$-proteobacteria, the phylogenic analysis showed some significant difference in the presence of bacteria species. For example, Tistrella mobilis was detected at the HRT of 17 and $11 \mathrm{~h}$, but it was not found in the HRT of 14 and $9 \mathrm{~h}$.

\section{Conclusion}

The average removal efficiencies of $\mathrm{COD}$ and $\mathrm{NH}_{4}{ }^{+}-\mathrm{N}$ decreased with the decrease in HRT, and no obvious accumulations of $\mathrm{NO}_{3}{ }^{-}-\mathrm{N}$ and $\mathrm{NO}_{2}{ }^{-}-\mathrm{N}$ in the effluent were found during the whole operational period. The increase in EPS with the decrease in HRT led to the increase in sludge volume index (SVI). The PN and PS in the EPS increased with the decrease in HRT, respectively. The PN/PS ratio decreased from 1.18 to 1.11 with the decrease in HRT from 17 to $9 \mathrm{~h}$. The SAOR, SNOR, SNNR, and SOUR increased with the decrease in HRT. The HRT variations have significant effect on the microbial community structures of the anoxic-aerobic SBR. The diversity indices of microbial community decreased from 2.69 to 2.39 with the decrease in HRT from 17 to $9 \mathrm{~h}$. The $\alpha$-proteobacteria were the dominant groups under HRT of 17, 14, 11, and $9 \mathrm{~h}$, which constituted $46,30,40$, and $40 \%$ of the whole microbial community, respectively.

Acknowledgments The work was funded by the National Natural Science Foundation of China (No. 51178437).

\section{References}

Barr TA, Taylor JM, Duff SJB (1996) Effect of HRT, SRT and temperature on the performance of activated sludge reactors treating bleached kraft mill effluent. Water Res 30:799-810

Boopathy R, Bonvillain C, Fontenot Q, Kilgen M (2007) Biologcial treatment of low-salinity shrimp aquaculture wastewater using sequencing batch reactor. Int Biodeterior Biodegrad 59(1):16-19

Campos J, Mosquera-Corral A, Sánchez M, Méndez R, Lema J (2002) Nitrification in saline wastewater with high ammonia concentration in an activated sludge unit. Water Res 36(10):2555-2560

Chang IS, Lee CH (1998) Membrane filtration characteristics in membrane-coupled activated sludge system-the effect of physiological states of activated sludge on membrane fouling. Desalination 120:221-233

Chen H, Zhou SG, Li TH (2010) Impact of extracellular polymeric substances on the settlement ability of aerobic granular sludge. Environ Technol 31:1601-1612

Chinese NEPA (2002) Water and wastewater monitoring methods, 4th edn. Chinese Environmental Science Publishing House, Beijing

Chistoserdova L, Lapidus A, Han C, Goodwin L, Saunders L, Brettin T, Tapia R, Gilna P, Lucas S, Richardson PM, Lidstrom ME (2007) Genome of Methylobacillus flagellatus, molecular basis for obligate methylotrophy, and polyphyletic origin of methylotrophy. J Bacteriol 189:4020-4027

Dan NP, Visvanathan C, Basu B (2003) Comparative evaluation of yeast and bacterial treatment of high salinity wastewater based on biokinetic coefficients. Bioresour Technol 87:51-56

de-Bashan LE, Moreno M, Hernandez JP, Bashan Y (2002) Removal of ammonium and phosphorus ions from synthetic wastewater by the microalgae Chlorella vulgaris coimmobilized in alginate beads with the microalgae growth-promoting bacterium Azospirillum brasilense. Water Res 36:2941-2948

Dubois M, Gilles KA, Hamilton JK, Rebers PA, Smith F (1956) Colorimetric method for determination of sugars and related substance. Anal Chem 28:350-356

Durai G, Rajasimman M, Rajamohan N (2011) Aerobic digestion of tannery wastewater in a sequential batch reactor by salt-tolerant bacterial strains. Appl Water Sci 1:35-40

Felsenstein J (1985) Confidence limits on phylogenies: an approach using the bootstrap. Evolution 39:783-791 
Fontenot Q, Bonvillain C, Kilgen M, Boopathy R (2007) Effects of temperature, salinity, and carbon: nitrogen ratio on sequencing batch reactor treating shrimp aquaculture wastewater. Bioresour Technol 98(9):1700-1703

Gebauer R (2004) Mesophilic anaerobic treatment of sludge from saline fish farm effluents with biogas production. Bioresour Technol 93(2):155-167

Han H, Zhang YY, Cui CC, Zheng SK (2010) Effect of COD level and HRT on microbial community in a yeast-predominant activated sludge system. Bioresour Technol 101:3463-3465

Hu Z, Zhang J, Xie HJ, Li SP, Wang JH, Zhang TT (2011) Effect of anoxic/aerobic phase fraction on $\mathrm{N}_{2} \mathrm{O}$ emission in a sequencing batch reactor under low temperature. Bioresour Technol 102:5486-5491

Hwang JH, Cicek N, Oleszkiewicz JA (2009) Inorganic precipitation during autotrophic denitrification under various operating conditions. Environ Technol 30:1475-1485

Isaka K, Kimura Y, Yamamoto T, Osaka T, Tsuneda S (2013) Complete autotrophic denitrification in a single reactor using nitritation and anammox gel carriers. Bioresour Technol 147:96-101

Jang D, Hwang Y, Shin H, Lee W (2013) Effects of salinity on the characteristics of biomass and membrane fouling in membrane bioreactors. Bioresour Technol 141:50-56. doi:10.1016/j. biortech.2013.02.062

Jørgensen KS, Pauli ASL (1995) Polyphosphate accumulation among denitrifying bacteria in activated sludge. Anaerobe 1:161-168

Jørgensen NOG, Brandt KK, Nybroe O, Hanse M (2009) Delftia lacustris sp. nov., a peptidoglycan-degrading bacterium from fresh water, and emended description of Delftia tsuruhatensis as a peptidoglycan-degrading bacterium. Int J Syst Evol Microbiol 59:2195-2199

Kapdan IK (2005) Kinetic analysis of dyestuff and COD removal from synthetic wastewater in an anaerobic packed column reactor. Process Biochem 40:2545-2550

Kargi F, Uygur A (2003) Nutrient removal performance of a five-step sequencing batch reactor as a function of wastewater composition. Process Biochem 38:1039-1045

Kim BY, Weon HY, Yoo SH, Kwon SW, Cho YH, Stackebrandt E, Go SJ (2006) Paracoccus homiensis sp. nov., isolated from a sea-sand sample. Int J Syst Evol Microbiol 56:2387-2390

Kim YM, Park DH, Jeon CO, Lee DS, Park JM (2008) Effect of HRT on the biological pre-denitrification process for the simultaneous removal of toxic pollutants from cokes wastewater. Bioresour Technol 99:8824-8832

Kumar S, Tamura K, Nei M (2004) MEGA3: integrated software for molecular evolutionary genetics analysis and sequence alignment. Brief Bioinform 5:150-163

Lai Q, Qiao N, Wu C, Sun F, Yuan J, Shao Z (2010) Stappia indica sp. nov., isolated from deep seawater of the Indian Ocean. Int J Syst Evol Microbiol 60:733-736

Lefebvre O, Moletta R (2006) Treatment of organic pollution in industrial saline wastewater: a literature review. Water Res 40:3671-3682

Lefebvre O, Vasudevan N, Torrijos M, Thanasekaran K, Moletta R (2005) Halophilic biological treatment of tannery soak liquor in a sequencing batch reactor. Water Res 39:1471-1480

Li XY, Yang SF (2007) Influnce of loosely bound extracellular polymeric substances (EPS) on the flocculation, sedmentation and dewaterability. Water Res 41:1022-1230

Li HY, Zhang Y, Yang M, Kamagata Y (2013) Effects of hydraulic retention time on nitrification activities and population dynamics of a conventional activated sludge system. Front Environ Sci Eng 7:43-48
Lowery OH, Rosebrough NJ, Farr AL, Randall RJ (1951) Protein measurement with the Folin phrnol reagent. J Biol Chem 193:265-275

Moussa MS, Hooijmans CM, Lubberding HJ, Gijzen HJ, van Loosdrecht MCM (2005) Modelling nitrification, heterotrophic growth and predation in activated sludge. Water Res 39:5080-5098

Moussavi G, Barikbin B, Mahmoudi M (2010) The removal of high concentrations of phenol from saline wastewater using aerobic granular SBR. Chem Eng J 158(3):498-504

Muda K, Aris A, Salim MR, Ibrahim Z, van Loosdrecht MCM, Ahmad A, Nawahwi MZ (2011) The effect of hydraulic retention time on granular sludge biomass in treating textile wastewater. Water Res 45:4711-4721

Muyzer G, de Waal EC, Uitterlinden AG (1993) Profiling of complex microbial populations by denaturing gradient gel electrophoresis analysis of polymerase chain reaction-amplified genes coding for 16S rDNA. Appl Environ Microbiol 59:695-700

$\mathrm{Ng}$ HY, Ong SL, Ng WJ (2005) Effects of sodium chloride on the performance of a sequencing batch reactor. J Environ Eng 131:1557-1564

Onyenwoke RU, Kevbrin VV, Lysenko AM, Wiegel J (2007) Thermoanaerobacter pseudethanolicus sp. nov., a thermophilic heterotrophic anaerobe from Yellowstone National Park. Int J Syst Evol Microbiol 57:2191-2193

Panswad T, Anan C (1999) Impact of high chloride wastewater on an anaerobic/anoxic/aerobic process with and without inoculation of chloride acclimated seeds. Water Res 33(5):1165-1172

Park SJ, Lee TW, Yoon TI (2004) Production of extracellular polymeric substances in anoxic/oxic process with zeolite carriers for nitrogen removal. Biotechnol Lett 26:1653-1657

Rene ER, Kim SJ, Park HS (2008) Effect of COD/N ratio and salinity on the performance of sequencing batch reactors. Bioresour Technol 99:839-846

Saitou N, Nei M (1987) The neighbor-joining method-a new method for reconstructing phylogenetic trees. Mol Biol Evol 4:406-425

Shannon CE, Weaver W (1949) The mathematical theory of communication. University of Illinois Press, Urbana

Sheng GP, Yu HQ, Li XY (2010) Extracellular polymeric substances (EPS) of microbial aggregates in biological wastewater treatment systems: a review. Biotechnol Adv 28:882-894

Shi BH, Arunpairojana V, Palakawong S, Yokota A (2002) Tistrella mobilis gen nov, sp nov, a novel polyhydroxyalkanoateproducing bacterium belonging to $\alpha$-Proteobacteria. J Gen Appl Microbiol 48:335-343

Shi K, Zhou WZ, Zhao HX, Zhang YZ (2012) Performance of halophilic marine bacteria inocula on nutrient removal from hypersaline wastewater in an intermittently aerated biological filter. Bioresour Technol 113:280-287

Wang X, Zeng RJ, Dai Y, Peng Y, Yuan Z (2008) The denitrification capability of cluster 1 Defluviicoccus vanus-related glycogenaccumulating organisms. Biotechnol Bioeng 99:1329-1336

Wang Y, Peng Y, Stephenson T (2009) Effect of influent nutrient ratios and hydraulic retention time (HRT) on simultaneous phosphorus and nitrogen removal in a two-sludge sequencing batch reactor process. Bioresour Technol 100:3506-3512

Xie CH, Yokota A (2006) Reclassification of [Flavobacterium] ferrugineum as Terrimonas ferruginea gen. nov., comb. nov., and description of Terrimonas lutea sp. nov., isolated from soil. Int J Syst Evol Microbiol 56:1117-1121

Yang HJ, Shao P, Lu TM, Shen JQ, Wang DF, Xu ZN, Yuan X (2006) Continuous bio-hydrogen production from citric acid wastewater via facultative anaerobic bacteria. Int $\mathrm{J}$ Hydrogen Energy 31:1306-1313

Zhang XQ, Bishop PL (2001) Spatial distribution of extracellular polymeric substances in biofilms. J Environ Eng 127:850-856 
Zhang ZP, Show KY, Tay JH, Liang DT, Lee DL, Jiang WJ (2006) Effect of hydraulic retention time on biohydrogen production and anaerobic microbial community. Process Biochem 41:2118-2123
Zhang ZJ, Chen SH, Wang SM, Luo HY (2011) Characterization of extracellular polymeric substances from biofilm in the process of starting-up a partial nitrification process under salt stress. Appl Microbiol Biotech 89:1563-1571 